\title{
Platinum-Group Element Geochemistry of the Devonian Arc Picrites from the North Junggar Terrane, NW China: Implications for Petrogenesis
}

\author{
Zhaochong Zhang ${ }^{1, *}$, Jinghong Cai $^{1}$, Gang Zhou ${ }^{2}$ and Timothy M. Kusky ${ }^{3}$
}

${ }^{I}$ State Key Laboratory of Geological Processes and Mineral Resources, China University of Geosciences, Beijing, 100083, China; ${ }^{2}$ No. 4 Geological Party, Xinjiang Bureau of Geology and Mineral Resources, Altai, 836500, China and ${ }^{3}$ Department of Earth and Atmospheric Sciences, St. Louis University, 3507 Laclede avenue, St. Louis, MO 63103-2010, $U S A$

\begin{abstract}
Picritic (MgO>12\%) and ankaramitic Devonian arc lavas in the north Junggar terrane provide a rare opportunity to evaluate the platinum group elements (PGE) of subduction-generated melts. The picrites are highly porphyritic with olivine, and rare clinopyroxene and chrome spinel $[\mathrm{Cr} \#(\mathrm{Cr} / \mathrm{Cr}+\mathrm{Al})=0.63-0.86]$ phenocrysts, embedded in a matrix of groundmass plagioclase, clinopyroxene, and magnetite, while clinopyroxene phenocrysts are dominant in the ankaramite. Minor metal sulfides (pyrrhotite, chalcopyrite, and pentlandite) are present. Despite their highly magnesian nature, the lavas contain relatively low concentrations of PGE's (0.2-0.6 ppb Ir, 5.6-7.1 ppb Pt, 3.1-7.0 ppb Pd) compared with other high- $\mathrm{MgO}$ lavas such as kimberlites, komatiites and plume-related picrites, but higher than those from other arc picrites, such as the Lesser Antilles arc in the Atlantic. The primitive mantle normalized PGE patterns are characterized by enrichment of the palladium group elements (PPGE) relative to iridium group elements (IPGE), which resembles those from the Lesser Antilles and Izu-Bonin arcs. Thus, it would appear that melts generated in a subduction regime may have common characteristics. Such low PGE concentrations are probably related to relatively low degrees of partial mantle melting. The picritic lavas have high Os/Ir ratios (>1), possibly reflecting the involvement of pelagic sediments. A Pd/Ir versus $\mathrm{Ni} / \mathrm{Cu}$ diagram implies that both picrites and ankaramites were not primary magmas, but high-MgO basalts with excess olivine or clinopyroxene respectively, whereas a $\mathrm{Pd}$ versus $\mathrm{Cu}$ diagram suggests $\mathrm{S}$-undersaturated primary magma. The PPGE may have slightly enhanced transport efficiency in slab-derived fluids compared to IPGE.
\end{abstract}

Key Words: Picrites, island arc, platinum-group element, Junggar terrane.

\section{INTRODUCTION}

In recent years, the geochemistry of platinum group elements (PGEs) has received increased attention. This is because, as highly siderophilic and mostly compatible elements, PGEs provide complementary information about the Earth's accretion, core-mantle differentiation, mantle evolution and magma genesis to that which can be derived from lithophilic incompatible elements [1-3]. The behavior of PGEs during partial melting and crystal fractionation can be studied from PGE compositions of mantle-derived lavas such as basalts and picrites. However, the PGE abundances of the mantle are difficult to infer from basalts, because PGE abundances in basalts are drastically reduced, and interelement ratios modified by extensive PGE fractionation in sulfide-saturated magmas $[4,5]$. In contrast, highly magnesian, near-primitive picritic and ankaramitic lavas have been used to infer the siderophile element content of the mantle [2]. This is possible because of the specific conditions of picrite and ankaramite formation, including high temperature partial melting, consistent with formation of picritic and ankaramitic magmas from mantle plumes [6, 7], sulfur under-saturation, rapid adiabatic ascent, and eruption at

*Address correspondence to this author at the State Key Laboratory of Geological Processes and Mineral Resources, China University of Geosciences, Beijing, 100083, China; E-mail: zczhang@cugb.edu.cn temperatures close to the liquidus. These conditions ensure that little fractionation occurs prior to eruption [8].

Picrites are characterized by $\mathrm{MgO}$ contents of more than $12 \mathrm{wt} \%, \mathrm{SiO}_{2}$ contents lower than $45 \mathrm{wt} \%$ and less than 3 wt $\%$ alkalies [9]. Picrites occur in different tectonic environments, including large igneous provinces (LIP), rift systems such as West Greenland [10], at mid-ocean ridges [11], and in island arcs [12]. However, the few occurrences reported in the literature are all confined to intra-oceanic and intra-continental regimes. Island arc picrites are only reported from the Aleutians [12], the Lesser Antilles [13], Kamchatka [14], Japan [15], Vanuatu [16] and from the Solomon Islands [17]. It is not fully understood, however, whether the parental magmas in island arcs are of picritic or basaltic composition. Based on a study of island arc volcanic (IAV) rocks from Grenada, Lesser Antilles, Woodland et al. proposed that subduction-related picritic magmas can be parental magmas of associated basalts [13]. In contrast to this model, other occurrences of subduction-related picrites like those in Vanuatu appear to be linked to anomalous thermal regimes such as the subduction of a complexly fractured segment (d'Entrecasteaux fracture zone) of the IndianAustralian plate beneath Vanuatu [18].

Recently, we recognized a near $100 \mathrm{~m}$-thick sequence of picritic lava flows in a Devonian arc in the north Junggar 
terrane, which lies in the middle part of Central Asian Orogenic Belt (CAOB). In this paper we report new PGE data for these picritic lavas (including ankamarites), and use these data to try to shed light into processes of partial melting and mantle behavior of PGEs in a subduction regime.

\section{GEOLOGICAL SETTING}

The Junggar terrane is bounded between the Siberian and Kazakhstan cratonic blocks on the north and the Tianshan Range on the south (Fig. 1a). It is traditionally divided into the East and West Junggar terranes and the Junggar Basin (Fig. 1b). The Junggar Basin is overlain by thick continental deposits and is bounded on the south by the south-dipping active foreland thrust zone of the Tianshan, which is composed mainly of an EW-striking volcanic arc complex. The East Junggar terrane is composed of several NW-SE striking, highly deformed metasedimentary and ophiolitic assemblages that were accreted to the southern margin of the Siberian craton along the Irtysh Fault (Fig.1c). The West Junggar was accreted to the Kazakhstan block to the west during Late Palaeozoic time [19].
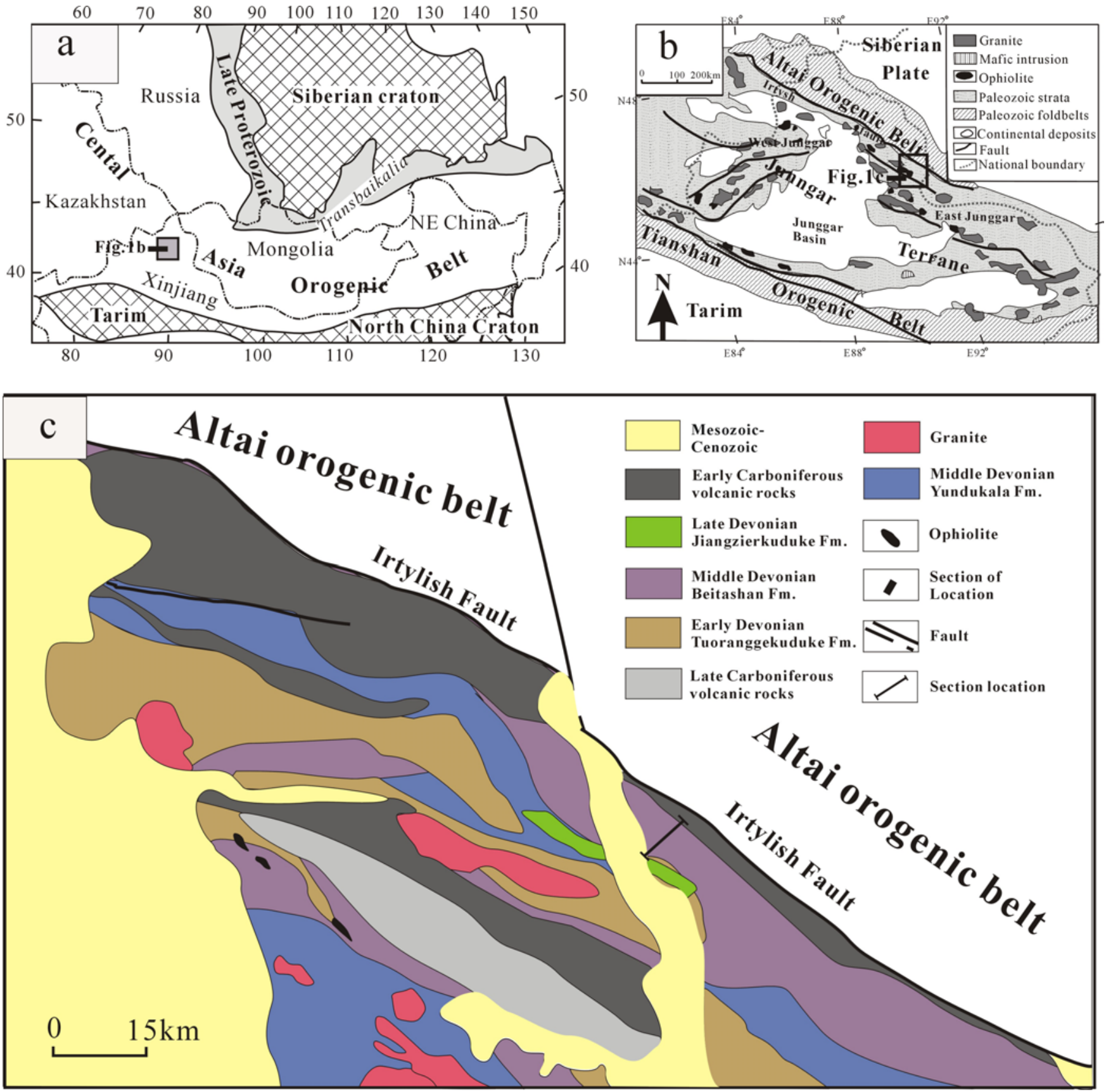

Fig. (1). (a) Relationship of study area with the Central Asia Orogenic Belt (modified from [58]); (b) Simplified geological map of the Junggar terrane in northern Xinjiang (modified from [59]; (c) Distribution of Palaeozoic volcanic rocks in the East Junggar terrane. The geology of the Altai orogenic belt in the north side of the Irtylish Fault is not shown. 
Picritic rocks were recently recognized in the east Junggar terrane [20], which is comprised of several accretionary complexes that were generated by subduction-accretion processes in Paleozoic times [21, 22]. The Junggar terrane is divided by two highly deformed and dismembered belts of ophiolites, including the Wulunguhe and Kalamaili ophiolites. The Wulunguhe ophiolite has been dated using SHRIMP U-Pb methods to be 481-489 Ma by Jian et al. [23], whereas Kalamaili ophiolite was determined to be $373 \mathrm{Ma}$ old [24]. These ophiolites reflect the formation of oceanic crust in the early to middle Palaeozoic. Subduction of oceanic crust beneath the Altai orogen and Kazakhstan plate is manifested by the presence of thick marine volcanoclastic rocks and volcanic flows intercalated with sediments of Devonian to Carboniferous ages. This was followed by accretion and imbrication of arc series magmatic rocks and backarc basins towards the Kazakhstan block as the three terranes (Tarim, Kazakhstan and Siberian) converged. The termination of these oceanic systems during the Carboniferous is

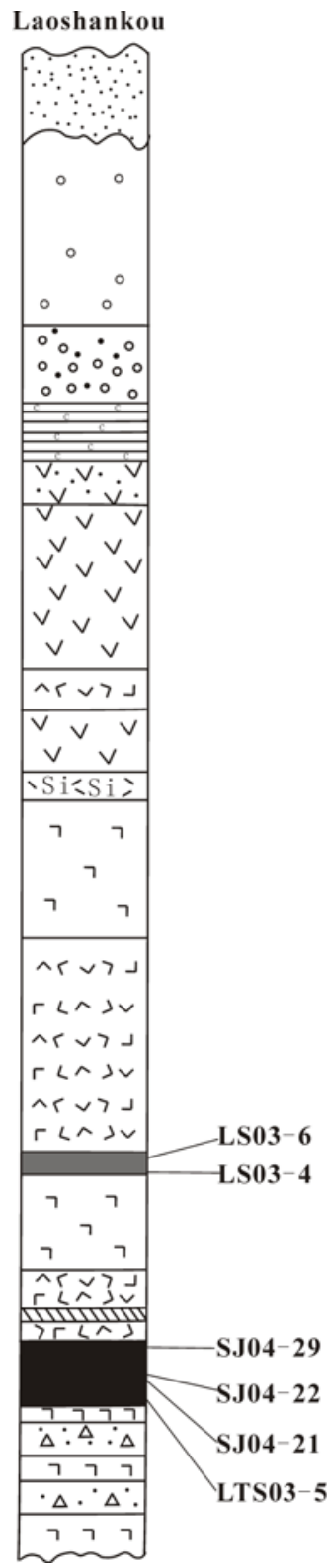

indicated by continental deposits that abruptly transgress over the earlier Palaeozoic marine facies deposits. Postcollisional magmatic rocks (mainly granitoids and $\mathrm{Cu}-\mathrm{Ni}$ bearing mafic and ultramafic rocks) intruded the foldbelt in late Carboniferous to early Permian times [25].

The strata outcropping in the east Junggar terrane includes a Devonian to Carboniferous marine volcanic-sedimentary sequence, a Permian continental volcanic-sedimentary sequence, and Mesozoic coal-bearing sedimentary rocks. All Paleozoic strata strike northwest, and dip northeast. The early Devonian Tuoranggekuduke Formation is the oldest in the Junggar terrane, and lies at the southernmost boundary of the terrane, whereas the Carboniferous strata is distributed in the north. This relationship is usually attributed to northward subduction of the Junggar ocean [20]. Picrites were discovered in the lower part of middle Devonian Beitashan Formation (Fm.), which consists chiefly of basic and intermediate lavas and corresponding pyroclastic rocks (Fig. 2), striking continuously NW. The Beitashan Fm. can be

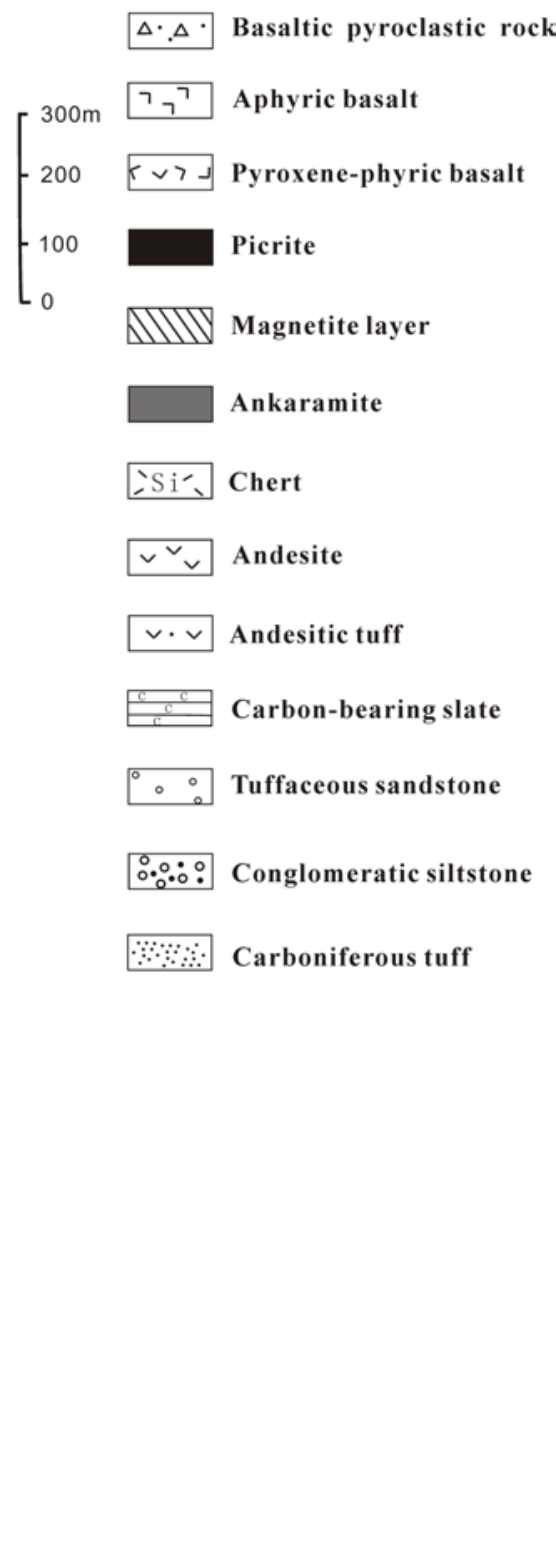

Fig. (2). Simplified stratigraphic columns of the Laoshankou section with sample localities. 
divided into three parts from base to top. The lower part consists of basalt, basaltic tuff, basaltic breccia, picrite and ankaramite intercalated with a 2-20 m thick magnetite layer. The picritic lava flows become thicker toward the southeast. Ankaramite is distributed at the top of this lower section. The basalts contain massive aphyric basalts with minor pyroxene-phyric basalts. The second section is composed of aphyric basalts alternating with pyroxene-phyric basalts, each forming a 2-10 m thick layer overlain by a 300-m-thick andesitic lava flows at higher levels. The third section includes sedimentary tuff, chert, siltstone and sandstone.

Although the isotopic age of the Beitashan Fm. has not been reported, it can be inferred that it formed in the Middle Devonian. This estimate is based on fossils hosted in the Beitashan Fm., such as Brachiopoda (Mucrospirifer mucronatus, Acrospirifer sp., Tridensills sp., Spinatrypa sp.), Bryozoan (Fenestella sp.) and plant fossils (Lepidosigillaria), that indicate a Middle Devonian age. Secondly, based on SHRIMP U-Pb zircon dating, Zhang et al. obtained a 376$381 \mathrm{Ma}$ age data from granitic porphyries which intruded the Beitashan Fm., and a 408 Ma age from the Tuoranggekuduke Fm. which is overlain by the Beitashan Fm. [26]. Thus, it can be inferred that the Beitashan Fm. formed in Middle Devonian times.

\section{PETROGRAPHY}

Picritic rocks are highly porphyritic. Based on phenocryst assemblages, they can be divided into two types. One is dominated by olivine phenocrysts, and we describe them as picrites. Another is dominated by clinopyroxene phenocrysts, and we describe them as ankaramites. Phenocryst assemblages in picrites are olivine (up to $30 \mathrm{vol} \%$ ) and minor clinopyroxene and $\mathrm{Cr}$-spinel $[\mathrm{Cr} \#(\mathrm{Cr} / \mathrm{Cr}+\mathrm{Al})=0.63$ 0.86], embedded in a matrix of groundmass granular olivine, clinopyroxene and minor plagioclase and Fe-Ti oxides. Most olivine phenocrysts are replaced by serpentine, but most grains retain cores of unaltered olivine. Some of them contain scattered melt inclusions. Olivine phenocrysts are usually $0.5-1 \mathrm{~mm}$ in diameter but occasionally exceed $2 \mathrm{~mm}$. They are usually cracked presumably because of stress during emplacement. Glass does not appear to be preserved. Minor small sulfides are scattered in the groundmass. The dominant phenocrysts in ankaramites are clinopyroxene, with subordinate olivine. The phenocrysts account for about $10-15$ vol \% of the rock. Clinopyroxene phenocrysts are relatively fresh, short, column-shaped, and some of them have been replaced by chlorite. Olivine phenocrysts have almost been replaced by epidote and actinolite, and only their outlines are retained. The groundmass consists chiefly of clinopyroxene, plagioclase and glass, with minor scattered magnetite and metal sulfides (pyrrhotite, chalcopyrite, and pentlandite). In addition, minor small Cr-spinel crystals (10$50 \mu \mathrm{m})$ are included in clinopyroxene phenocrysts.

\section{SAMPLE PREPARATION AND ANALYTICAL PROCEDURE}

Six samples of picrites and ankaramites were chosen for PGE analyses. These samples were the least altered available and were chosen on the basis of the following criteria: (1) macroscopic observation; (2) thin-section examination; (3) relative density and hardness. All original and altered sur- faces were removed from each of the samples with a watercooled rock saw and the interior portion was cut into a slab. All sawn surfaces were then removed using a diamond lap wheel. Each lapped slab was cleaned in de-ionized water in an ultrasonic bath for about 15 minutes, and dried under a heat lamp. The slab was placed inside a plastic bag, sealed with duct tape, and struck with a duct-tape-covered hammer to reduce the sample to small chips. About 100-200 g of chips was ground into powder in a pre-cleaned agate mortar. About $10 \mathrm{~g}$ of each sample powder was split for PGE analyses.

Analyses were carried out at the low-level PGE facility of the Chinese Academy of Geological Sciences in Beijing. PGE were separated by a NiS-fire assay and Tecoprecipitation method adapted from [27]. Ten grams of sample powder were mixed with $2 \mathrm{~g}$ of $\mathrm{Ni}_{2} \mathrm{O}_{3}$ (purified before use), $1.25 \mathrm{~g}$ of $\mathrm{S}, 15 \mathrm{~g}$ of $\mathrm{Na}_{2} \mathrm{CO}_{3}, 20 \mathrm{~g}$ of $\mathrm{Na}_{2} \mathrm{~B}_{4} \mathrm{O}_{7}, 1 \mathrm{~g}$ of $\mathrm{SiO}_{2}$ and $1 \mathrm{~g}$ of flour in a clay crucible (Flour is used to reduce the metal oxides to metal or alloy, and also used to reduce the high valence oxides to low valence in order to make slag with $\mathrm{SiO}_{2}$ more easily). An Os ${ }^{190}$ spike (from Oak Ridge National Laboratory in USA) which was kept in an alkaline medium before adding into the samples was then added. Under these reducing conditions, the spike and PGEs isotopically equilibrate within an immiscible NiS melt [28]. The mixture was baked at $1200^{\circ} \mathrm{C}$ for 1.5 hours in a fire-clay crucible to produce a NiS button as described by Ravizza and Pyle [28]. The NiS button was then crushed and dissolved in $\mathrm{HCl}$ and the PGE were collected by Te coprecipitation. After filtration, the precipitate was dissolved in $1 \mathrm{ml}$ of aqua regia in a sealed Teflon vessel at $100^{\circ} \mathrm{C}$ for $1 \mathrm{~h}$. The solution was then diluted to $10 \mathrm{ml}$ with $\mathrm{H}_{2} \mathrm{O}$ for measurement by inductively coupled plasma - mass spectrometry (ICP-MS) on a TJA PQ-EXCELL instrument. Os was determined by merely introducing the solution after dissolving the NiS buttons into ICP-MS. ${ }^{192} \mathrm{Os} /{ }^{190} \mathrm{Os}$ ratios are employed to calculate the concentration. The detailed ID-ICPMS procedure for Os was described by $\mathrm{Du}$ [29]. The total procedural blanks were less than $0.3 \mathrm{ng} / \mathrm{g}$ for $\mathrm{Ru}, \mathrm{Ir}, \mathrm{Pd}$ and Os, and $0.06 \mathrm{ng} / \mathrm{g}$ for $\mathrm{Pt}$ and $\mathrm{Rh}$. For the method of NiS-fireassay, the total procedural blank is dominantly from the flux, but it is also relatively stable (we have tested it several times before). Consequently, for all samples, it can be used to deduct the same value of blank for each of the corresponding elements. All PGE concentrations listed in Table $\mathbf{1}$ are the determined values deducted from the total procedure blanks. The results of analysis of reference material GPT-4 are consistent with the certified values (Table 1). The analytical uncertainties of PGE (2s) are within 4-20\%, i.e., $17.7 \%$ for Os, $19.8 \%$ for Ir, $18.9 \%$ for $\mathrm{Ru}, 15.7 \%$ for $\mathrm{Rh}, 3.8 \%$ for $\mathrm{Pt}$ and 11.9 for $\mathrm{Pd}$.

Bulk-rock major and trace element compositions were determined at the Chinese Academy of Geological Sciences. Major element determinations were done by X-ray fluorescence spectroscopy using the methods of Norrish and Chapell [30] and ferric and ferrous iron were determined by wet chemical method. The trace element abundances were determined by inductively coupled plasma - mass spectrometry (ICP-MS) following Dulski [31]. The precision of the analyses was generally $\sim 1 \%$ for major oxides, $\sim 0.5 \%$ for $\mathrm{SiO}_{2}$, and $3-7 \%$ for trace elements. Accuracy values are based on the average of repeated analysis of standard 
Table 1. PGE Analyses of the Picrites and Ankamarites of the Beitashan Formation, North Junggar Terrane

\begin{tabular}{|c|c|c|c|c|c|c|c|c|c|c|c|c|c|c|c|}
\hline Sample No. & LTS03-5 & LS03-6 & LS03-4 & SJ04-21 & SJ04-22 & SJ04-29 & \multirow[t]{2}{*}{ Average } & \multicolumn{2}{|c|}{ GT-4 } & \multirow{2}{*}{$\begin{array}{l}\text { PM } \\
{[34]}\end{array}$} & \multirow{2}{*}{$\begin{array}{c}\text { GP } \\
{[13]}\end{array}$} & \multirow{2}{*}{$\begin{array}{l}\text { HP } \\
{[2]}\end{array}$} & \multirow{2}{*}{$\begin{array}{c}\mathbf{K K} \\
{[2]}\end{array}$} & \multirow{2}{*}{$\begin{array}{c}\text { EP } \\
{[61]}\end{array}$} & \multirow{2}{*}{$\begin{array}{c}\text { RP } \\
{[43]}\end{array}$} \\
\hline Lithology & $\mathbf{P}$ & $\mathbf{A}$ & $\mathbf{A}$ & $\mathbf{P}$ & $\mathbf{P}$ & $\mathbf{P}$ & & $\mathbf{R M}$ & MV & & & & & & \\
\hline Os $\left(10^{-9}\right)$ & 1.02 & 0.52 & 0.57 & 0.80 & 0.41 & 0.93 & 0.71 & $2.4 \pm 0.6$ & 2.2 & 3.89 & $\begin{array}{c}0.04-0.09 \\
(0.07)\end{array}$ & $\begin{array}{c}0.227-1.083 \\
(0.72)\end{array}$ & $\begin{array}{c}1.16-1.83 \\
(1.64)\end{array}$ & $\begin{array}{c}3.3-8.2 \\
(5.50)\end{array}$ & $\begin{array}{c}2.22-4.05 \\
(2.92)\end{array}$ \\
\hline $\operatorname{Ir}\left(10^{-9}\right)$ & 0.62 & 0.21 & 0.22 & 0.56 & 0.25 & 0.64 & 0.42 & $4.7 \pm 1.1$ & 4.6 & 3.85 & $\begin{array}{c}0.06-0.12 \\
(0.08)\end{array}$ & $\begin{array}{c}0.17-1.32 \\
(0.55)\end{array}$ & $\begin{array}{c}1.25-1.65 \\
(1.59)\end{array}$ & $\begin{array}{c}0.85-2.19 \\
(1.21)\end{array}$ & $\begin{array}{c}1.82-2.61 \\
(2.09)\end{array}$ \\
\hline $\operatorname{Ru}\left(10^{-9}\right)$ & 1.58 & 0.60 & 1.12 & 1.51 & 1.12 & 1.61 & 1.26 & $2.5 \pm 0.2$ & 2.9 & 5.70 & $\begin{array}{c}0.15-0.23 \\
(0.20)\end{array}$ & $\begin{array}{c}0.458-1.48 \\
(0.94)\end{array}$ & $\begin{array}{c}3.43-4.7 \\
(4.05)\end{array}$ & $\begin{array}{c}1.3-3.2 \\
(2.28)\end{array}$ & $\begin{array}{c}4.12-5.21 \\
\quad(4.64)\end{array}$ \\
\hline $\operatorname{Rh}\left(10^{-9}\right)$ & 0.59 & 0.51 & 0.46 & 0.58 & 0.44 & 0.54 & 0.52 & $4.3 \pm 0.8$ & 3.3 & 1.07 & & & & $\begin{array}{c}0.31-0.5 \\
(0.39)\end{array}$ & $\begin{array}{c}0.63-1.4 \\
(0.96)\end{array}$ \\
\hline $\operatorname{Pt}\left(10^{-9}\right)$ & 6.53 & 6.53 & 6.55 & 7.07 & 6.68 & 5.61 & 6.50 & $58 \pm 5$ & 61 & 7.92 & $\begin{array}{c}1.88-3.91 \\
(2.88)\end{array}$ & $\begin{array}{c}2.06-5.94 \\
(3.86)\end{array}$ & $\begin{array}{c}5.89-10.3 \\
(8.19)\end{array}$ & $\begin{array}{c}3.58-10.6 \\
(7.45)\end{array}$ & \\
\hline $\operatorname{Pd}\left(10^{-9}\right)$ & 3.10 & 5.64 & 4.28 & 6.95 & 6.73 & 3.51 & 5.04 & $60 \pm 9$ & 59 & 4.48 & $\begin{array}{c}1.23-3.99 \\
(2.43)\end{array}$ & $\begin{array}{c}1.35-7.71 \\
(3.08)\end{array}$ & $\begin{array}{c}5.37-11.7 \\
(9.53)\end{array}$ & $\begin{array}{c}2.1-7.42 \\
(5.44)\end{array}$ & $\begin{array}{c}4.03-6.28 \\
\quad(5.06)\end{array}$ \\
\hline Os/Ir & 1.65 & 2.48 & 2.59 & 1.43 & 1.64 & 1.57 & 1.87 & & & & & & & & \\
\hline $\mathrm{Pd} / \mathrm{Os}$ & 3.04 & 10.85 & 7.51 & 8.69 & 16.41 & 3.77 & 7.10 & & & & & & & & \\
\hline $\mathrm{Pd} / \mathrm{Ir}$ & 5.00 & 26.86 & 19.45 & 12.41 & 26.92 & 5.48 & 12.00 & & & & & & & & \\
\hline $\mathrm{SiO}_{2}(\mathrm{wt} \%)$ & 47.85 & 49.65 & 49.72 & 46.01 & 48.26 & 48.41 & & & & & & & & & \\
\hline $\mathrm{TiO}_{2}(\mathrm{wt} \%)$ & 0.42 & 0.49 & 0.48 & 0.48 & 0.43 & 0.61 & & & & & & & & & \\
\hline $\mathrm{Al}_{2} \mathrm{O}_{3}(\mathrm{wt} \%)$ & 7.47 & 10.25 & 9.84 & 7.9 & 7.06 & 7.34 & & & & & & & & & \\
\hline $\mathrm{Fe}_{2} \mathrm{O}_{3}(\mathrm{wt} \%)$ & 4.19 & 5.06 & 5.04 & 7.1 & 5.88 & 3.17 & & & & & & & & & \\
\hline $\mathrm{FeO}(\mathrm{wt} \%)$ & 7.69 & 5.64 & 6.01 & 4.96 & 4.56 & 7.15 & & & & & & & & & \\
\hline $\mathrm{MnO}(\mathrm{wt} \%)$ & 0.21 & 0.19 & 0.2 & 0.19 & 0.16 & 0.19 & & & & & & & & & \\
\hline $\mathrm{MgO}(\mathrm{wt} \%)$ & 21.97 & 15.74 & 15.46 & 22.75 & 24.08 & 22.86 & & & & & & & & & \\
\hline $\mathrm{CaO}(\mathrm{wt} \%)$ & 9.29 & 9.86 & 10.24 & 9.64 & 8.42 & 8.92 & & & & & & & & & \\
\hline $\mathrm{Na}_{2} \mathrm{O}(\mathrm{wt} \%)$ & 0.44 & 1.67 & 1.9 & 0.44 & 0.61 & 0.69 & & & & & & & & & \\
\hline $\mathrm{K}_{2} \mathrm{O}(\mathrm{wt} \%)$ & 0.2 & 1.23 & 0.86 & 0.17 & 0.29 & 0.34 & & & & & & & & & \\
\hline $\mathrm{P}_{2} \mathrm{O}_{5}(\mathrm{wt} \%)$ & 0.28 & 0.24 & 0.24 & 0.35 & 0.24 & 0.31 & & & & & & & & & \\
\hline LOI (wt $\%)$ & 4. 4 & 3. 91 & 4. 01 & 4. 09 & 5.01 & 3.27 & & & & & & & & & \\
\hline $\mathrm{Mg} \#$ & 81 & 77 & 77 & 82 & 84 & 84 & & & & & & & & & \\
\hline $\mathrm{La}\left(10^{-6}\right)$ & 4.7 & 4.59 & 2.8 & 5.69 & 3.69 & 5.57 & & & & & & & & & \\
\hline $\mathrm{Ce}\left(10^{-6}\right)$ & 10.8 & 10 & 6.89 & 11.96 & 7.74 & 11.16 & & & & & & & & & \\
\hline $\operatorname{Pr}\left(10^{-6}\right)$ & 1.59 & 1.37 & 1.08 & 1.72 & 1.14 & 1.53 & & & & & & & & & \\
\hline $\mathrm{Nd}\left(10^{-6}\right)$ & 7.61 & 6.22 & 5.34 & 8.61 & 5.79 & 7.63 & & & & & & & & & \\
\hline $\operatorname{Sm}\left(10^{-6}\right)$ & 2.01 & 1.8 & 1.73 & 2.45 & 1.53 & 2.1 & & & & & & & & & \\
\hline $\mathrm{Eu}\left(10^{-6}\right)$ & 0.65 & 0.58 & 0.6 & 0.64 & 0.46 & 0.77 & & & & & & & & & \\
\hline $\operatorname{Gd}\left(10^{-6}\right)$ & 1.89 & 1.93 & 2.02 & 2.17 & 1.65 & 2.34 & & & & & & & & & \\
\hline $\operatorname{Tb}\left(10^{-6}\right)$ & 0.28 & 0.33 & 0.33 & 0.32 & 0.26 & 0.39 & & & & & & & & & \\
\hline Dy $\left(10^{-6}\right)$ & 1.65 & 2.13 & 2.18 & 1.99 & 1.6 & 2.35 & & & & & & & & & \\
\hline Ho $\left(10^{-6}\right)$ & 0.33 & 0.43 & 0.44 & 0.43 & 0.34 & 0.53 & & & & & & & & & \\
\hline $\operatorname{Er}\left(10^{-6}\right)$ & 0.9 & 1.24 & 1.29 & 1.09 & 0.92 & 1.38 & & & & & & & & & \\
\hline $\operatorname{Tm}\left(10^{-6}\right)$ & 0.13 & 0.18 & 0.19 & 0.17 & 0.14 & 0.21 & & & & & & & & & \\
\hline
\end{tabular}


(Table 1) contd....

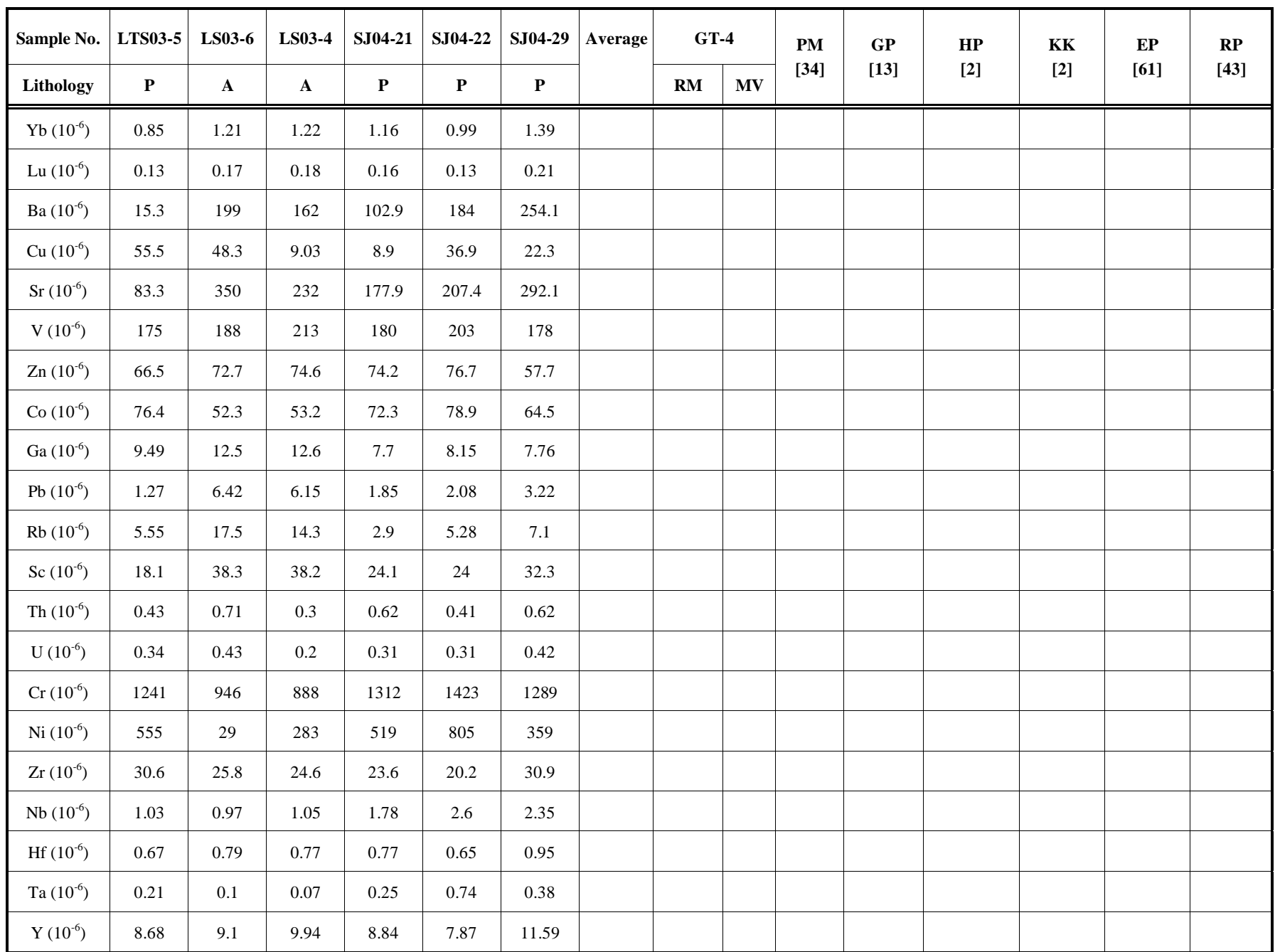

$\mathrm{Mg}=$ atomic $\mathrm{Mg} /\left(\mathrm{Mg}+\mathrm{Fe}^{2+}\right)$. Abbreviations: $\mathrm{P}=$ picrite; $\mathrm{A}=$ ankaramite; $\mathrm{RM}=$ reference material; $\mathrm{MV}=$ measured values for $\mathrm{RM}$; $\mathrm{PM}=\mathrm{primitive}$ mantle; $\mathrm{GP}=\mathrm{Grenada}$ picrite; $\mathrm{HP}=$ Hawaian picrite; $\mathrm{KK}=$ Kostomuksha komatiite; $\mathrm{EP}=$ Emeishan picrite; $\mathrm{RP}=$ Ronda peridotite (Spain). The analyses are recalculated to $100 \%$ volatile-free. The number in brackets is average value.

BHVO-1. Major elements were measured on Siemens 303AS and 3080E spectrometers, and trace elements on VG PQ-2 Turbo and PQ-2S instruments.

\section{RESULTS}

The PGE data for the picrites and ankaramites are listed in Table 1. The picrites and ankaramites have a limited range of PGE concentrations (Table 1). Thus, we use "picritic rocks" to represent picrites and ankaramites. Concentrations of picritic rocks range between 0.41 and $1.02 \mathrm{ppb}$ for Os, 0.21 and $0.64 \mathrm{ppb}$ for $\mathrm{Ir}, 0.60$ and $1.61 \mathrm{ppb}$ for $\mathrm{Ru}, 0.41$ and $0.59 \mathrm{ppb}$ for $\mathrm{Rh}, 5.61$ and $7.07 \mathrm{ppb}$ for $\mathrm{Pt}$, and 3.10 and 6.95 ppb for Pd (Table 1). Sample SJ04-22 is high in $\mathrm{MgO}$ but distinctly low in Os and Ir compared with other picrites. It could be attributed to relatively lower degree of partial melting because Os and Ir are compatible elements during mantle melting $[32,33]$

Compared with Hawaian picrites [34], the Junggar picritic rocks have similar Ir-group PGE (Os, Ir and $\mathrm{Ru}$, IPGE) concentrations, but slightly higher Pd-group PGE
(Rh, Pt and Pd, PPGE). In contrast, they have slightly lower IPGE contents, and approximately same PPGE contents in comparison with the Emeishan picrites (Table 1). All PGE contents of the Junggar picritic rocks are much lower than Kostomuksha komatiites [2], but much higher than arc picrites, such as the Grenada picrites, from the Lesser Antilles arc [13]. Compared with the large igneous province (LIP) picrites with the same $\mathrm{MgO}$ contents, the Junggar picrites have similar Os contents, such as Hawaian and Karoo (South Africa) picrites, but significantly lower other PGEs compared with the Siberian and Emeishan picrites (Fig. 3). However, it is noted that the Siberian and Emeishan LIPs host $\mathrm{Cu}-\mathrm{Ni}$-PGE deposits, while no PGE deposits have been found in the Junggar terrane.

The Os/Ir ratios of the Junggar picrites range from 1.43 to 2.59 , demonstrating Os enrichment relative to Ir. The $\mathrm{Pd} / \mathrm{Os}$ ratios are within 5 and 27, suggesting PPGE enrichment relative to IPGE. All picritic rocks have similar primitive mantle-normalized PGE patterns characterized by PPGE enrichment relative to IPGE and negatively Ir anomalies (Fig. 4). 


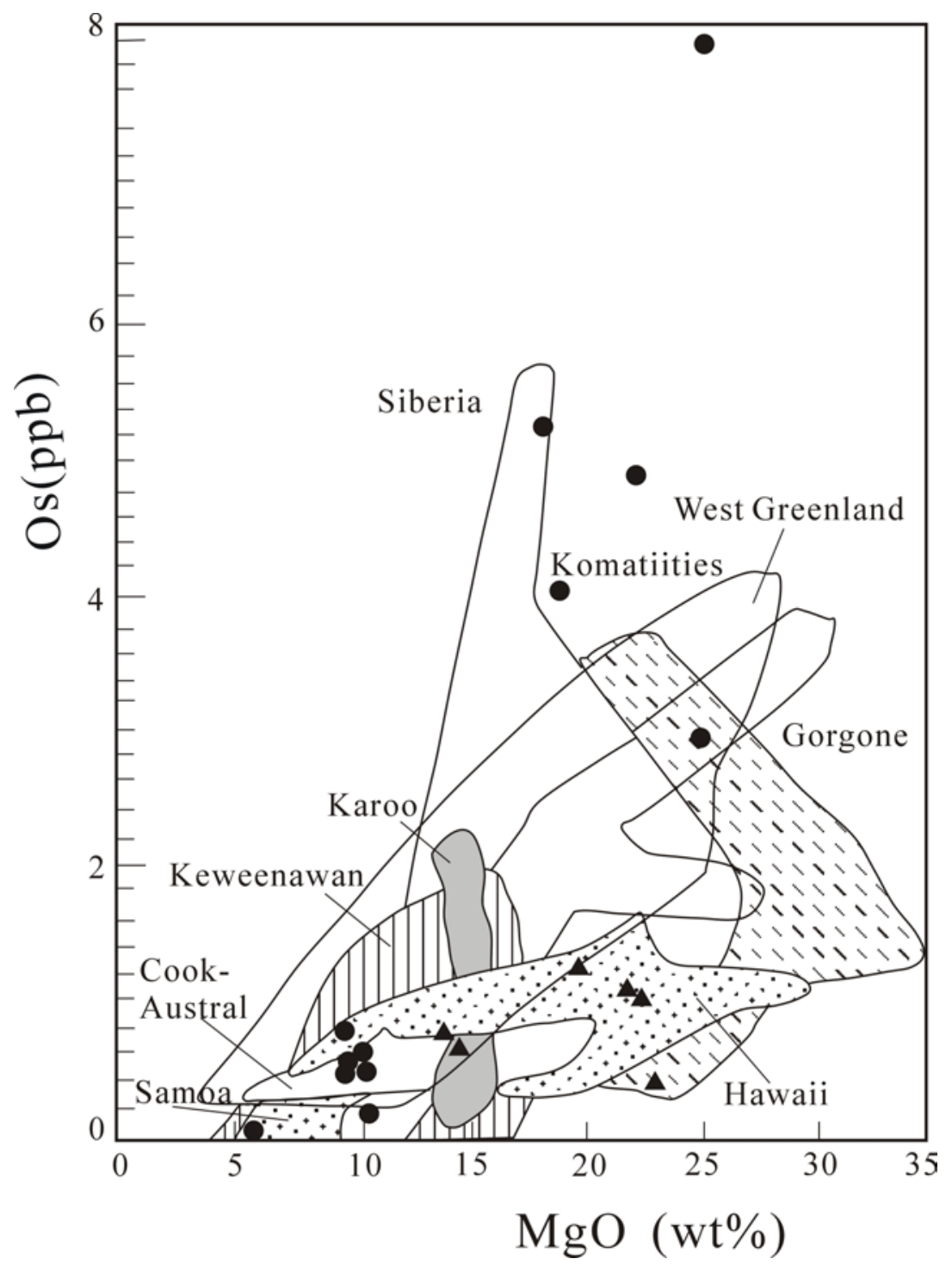

Fig. (3). $\mathrm{MgO}$ vs. Os diagram of picrites and ankaramites of the Beitashan Formation, north Junggar terrane. Filled triangle: Junggar picrites and ankamarites; filled circle: Emeishan picrites. Data sources: West Greenland, Siberia, Gorgone, Karoo, Keweenawan, Cook-Austral, Hawaii and Samoa from [60] and therein, and Emeishan from [61].

\section{DISCUSSION}

\subsection{Alteration Affects}

The volcanic rocks of the Beitashan Fm. have undergone weak alteration during greenschist facies metamorphism as exhibited by their weight loss on ignition. Previous studies have suggested that under such metamorphic conditions, Al, $\mathrm{Ca}$ and $\mathrm{Mg}, \mathrm{Cu}$ and $\mathrm{Ni}$ are relatively immobile [35]. Additionally, the PGEs are immobile during low-temperature alteration [36, 37]. Therefore it can be inferred that these elements may have remained immobile, and can reflect those of the original magmatic rocks.

\subsection{Mantle Sources}

Based on trace element geochemistry of the picrites and basalts from the Beitashan Fm., Zhang et al. discussed the mantle sources and tectonic setting, and proposed that the volcanic rocks of the Beitashan Fm. were generated from an arc setting, and derived from incompatible elements-depleted asthenospheric mantle metasomatized by slab-derived fluids [38].

For undifferentiated mantle-derived magmas, their $\mathrm{Pd}$ contents are close to $\mathrm{Ir}$ contents, and $\mathrm{Pt} / \mathrm{Pt}^{*}=(\mathrm{Pt} / 8.3)[(\mathrm{Rh} /$ 1.6) $\times(\mathrm{Pd} / 4.4)]^{1 / 2} \approx 1$ [39]. Thus, the $\mathrm{Pd} / \mathrm{Ir}$ and $\mathrm{Pt} / \mathrm{Pt}^{*}$ diagram can be utilized to infer if the magmas were derived from incompatible element-depleted asthenospheric mantle or differentiated primary mantle (Fig. 5). Fig. (5) shows that the Junggar picrites were derived from incompatible elementdepleted asthenospheric mantle, and all picritic rocks were generated by similar degrees of partial melting of incompatible element-depleted asthenospheric mantle.

The Junggar picritic rocks have slightly higher PGE concentrations than those from other arc picrites such as the Grenada picrites, but much lower PGE concentrations than those from other tectonic settings, such as plume-related picrites, including the Hawaian and Emeishan picrites (Table 1), even though the Junggar picritic rocks contain minor 


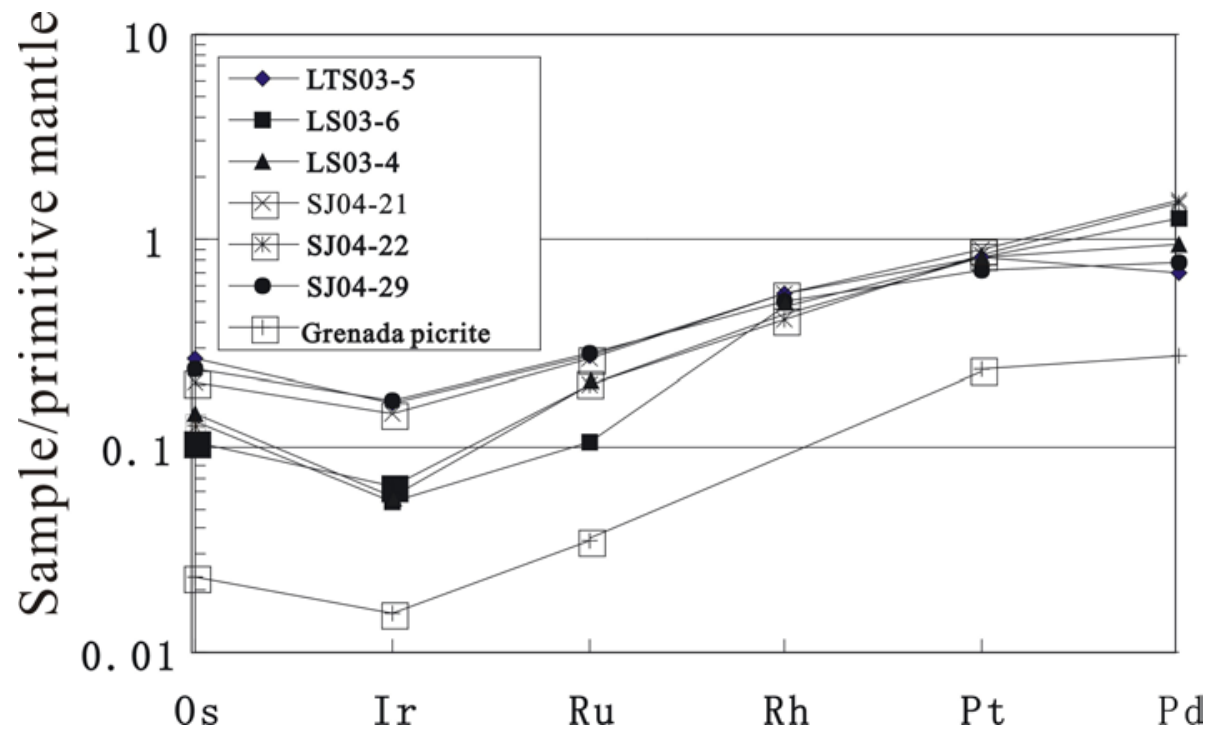

Fig. (4). Primitive mantle normalized PGE patterns of the picrites and ankaramites of the Beitashan Formations. Normalized values are from [34].

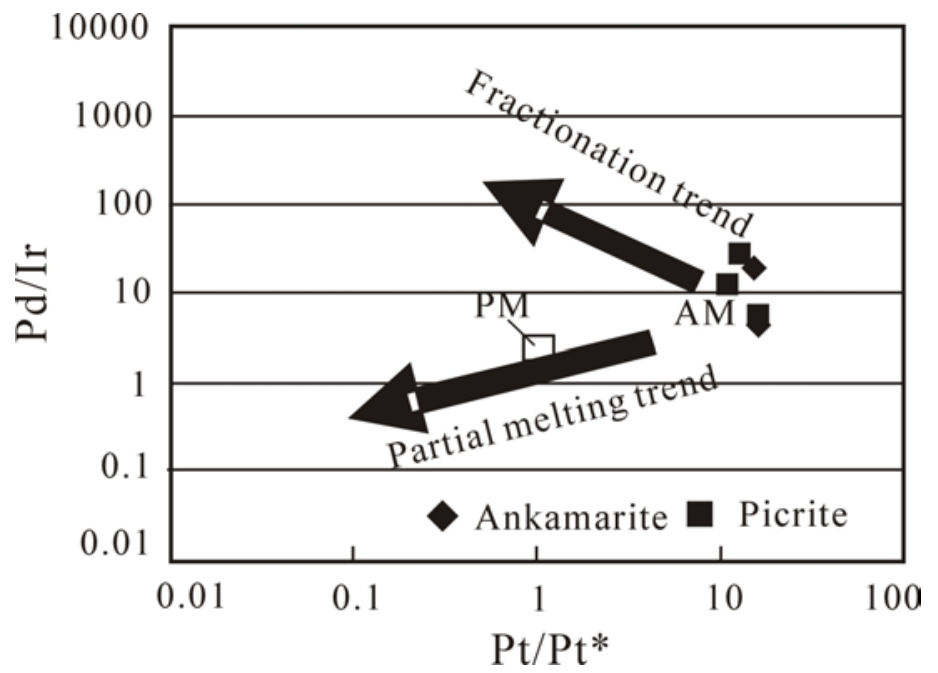

Fig. (5). Diagram of $\mathrm{Pd} / \mathrm{Ir}$ vs. $\mathrm{Pt} / \mathrm{Pt} \mathrm{P}^{*}$ as an indicator for discriminating the nature of mantle (based on $\left.[39]\right) . \mathrm{Pt} / \mathrm{Pt} t^{*}=(\mathrm{Pt} / 8.3)[(\mathrm{Rh} / 1.6) \times(\mathrm{Pd} /$ $4.4)]^{1 / 2}$. AM=asthenospheric mantle (depleted) [39]; $\mathrm{PM=primitive} \mathrm{mantle} \mathrm{[39].}$

primary sulfides. One possible interpretation for the varying PGE concentrations of picrites within different tectonic settings could be related to the extent of partial mantle meltinghigher degrees of melting correlate with higher PGE abundances in the resulting lavas. This conclusion is supported by the following facts. The Grenada picrites were generated by $\sim 10 \%$ partial mantle melting [40], whereas the Junggar picrites are the products of $\sim 15 \%$ melting of mantle [38], and plume-related picritic magmas result from much higherdegree partial melting of $\sim 25 \%$ [41]. Another possible reason for the low PGE concentrations of subduction-generated picrites could be related to the involvement of sediments in the mantle source or slab-derived fluids during subduction.

It is generally believed that Os and Ir behave in an identical manner during mantle melting and fractional crystallization, because of the near-uniform Os/Ir ratios of $\sim 1$ that have been observed in mantle peridotite and high-degree partial melts such as komatiites [42]. However, the Junggar picrites have subchondritic Os/Ir ratios, ranging from 1.43 to 2.59, 1.43 to 1.65 for picrites and 2.48 to 2.59 for ankamarites (Table 1). Thus, high Os/Ir values cannot be attributed to magmatic processes. The mechanisms of fractionating Os from Ir are still uncertain. There are three possible reasons for elevated Os/Ir ratios. The first possibility is that Os concentrations in some of the picrites may have increased since eruption through the radiogenic in-growth of ${ }^{187} \mathrm{Os}$ via the decay of ${ }^{187}$ Re. This effect can be observed in some basalts and other rocks with high ${ }^{187} \mathrm{Os} /{ }^{188} \mathrm{Os}$ and high Re/Os. Although we have neither Os isotopic compositions nor $\mathrm{Re}$ concentrations for the picritic rocks, this explanation is unlikely because picrites in general tend to have low Re/Os compared to basalts and, given typical Re/Os values in the picrites, $380 \mathrm{Myr}$ is not enough time to markedly increase the total Os concentration by addition of ${ }^{187}$ Os. Hence, this possibility can be excluded. The second possibility of high $\mathrm{Os} / \mathrm{Ir}$ is interpreted in terms of mobilization of Os by late magmatic fluids, as exhibited in the Ronda lherzolites [43]. 
However, the Os/Ir ratios of the Junggar picritic rocks are much higher than those at Ronda ( 1.37). Thus, it is unlikely that the high Os/Ir ratios result from the effects of late magmatic fluids although we cannot exclude the possibility of resulting from Os mobilization by late magmatic fluids. The third possibility is that some picritic magmas were contaminated by trace metal-rich black shales, which typically exhibit superchondritic Os/Ir ratios [28]. The previous studies have shown that black shales are generally characterized by high total organic carbon and total sulfur contents as well as by high Os concentrations, extremely high Re/Os [44], and high Re and Os concentrations can be attributed to high organic carbon in black shales [44]. Thus, the extremely high $\mathrm{Re} / \mathrm{Os}$ ratios resulted in the very radiogenic Os isotopic composition leading to superchondritic Os/Ir ratios over time. In the Junggar terrane, some black shales are associated with the Wulunguhe ophiolite, which yields SHRIMP U-Pb zircon ages of 481-489 $\mathrm{Ma}$, and represents ancient midoceanic ridge [23]. Thus, it is likely that the black shales were subducted into the mantle wedge. Although the contribution from plegic sediments into magmas might be limited, it would significantly affect PGE abundances and Os/Ir ratios of the Junggar sub-arc mantle. Therefore, we infer that the elevated Os/Ir ratios might be related to melting of incompatible elements-depleted asthenospheric mantle which involved plegic sediments like black shales.

\subsection{Nature of Primary Magmas}

It is generally believed that picrites represent the compositions of primary magmas generated by partial melting of mantle, or partial melting of mantle with the accumulation of excess olivine crystals [45]. Microprobe analyses of olivine phenocrysts reveals that the Fo contents of olivine phenocrysts in the Junggar picritic rocks range from 80-81, and 7880 for the matrix olivines. Based on olivine-melt equilib- rium, $\mathrm{MgO}$ content of the primary magmas can be estimated to be $\sim 9 \mathrm{wt} \%$, much lower than those of the picrites and ankaramites $(\sim 23 \mathrm{wt} \%$ and $\sim 16 \mathrm{wt} \%)$ [38]. Therefore these lavas cannot represent the primary melts generated by partial melting of mantle, but the primary magmas with cumulus olivine or clinopyroxene crystals [38].

The magmas with different mantle sources have distinct $\mathrm{Pd} / \mathrm{Ir}$ and $\mathrm{Ni} / \mathrm{Cu}$ ratios [46]. Hence, these ratios can be utilized to discriminate the nature of primary magmas (Fig. 6). The Junggar picritic rocks plot within the field of high-Mg basalts, but not in the field of komatiites. However, the Junggar picrite and ankaramite samples have much higher $\mathrm{MgO}$ contents $(\sim 23 \mathrm{wt} \%$ and $\sim 16 \mathrm{wt} \%)$ than those of the high$\mathrm{MgO}$ basalts defined by Chai and Naldrett [46]. It suggests that the Junggar picritic rocks are not the counterpart of primary magmas generated by partial melting of mantle, and some high-Mg minerals should be involved in the primary magmas. Based on their petrographic observation (phenocrysts), we can conclude that the Junggar picrites and ankaramites formed by the primary magmas with cumulus olvine and clinopyroxene crystals respectively. This is consistent with the conclusion from olivine-melt equilibrium.

Previous studies have shown that the host minerals of PGE in the mantle are most likely not silicates, but sulfides and PGE alloys [4, 47, 48]. The Ni-Cu sulfide melt-silicate partition coefficients (D) for PGE determined experimentally are on the order of $10^{4}-10^{5}[49,50]$. Thus, the PGE contents in primary melts dominantly depend on whether the magmas are S-saturated or S-undersaturated because sulfide-saturated magmas would have been stripped of PGE. Although both $\mathrm{Cu}$ and $\mathrm{Pd}$ tend to be compatible with sulfides, $\mathrm{Pd}$ is more compatible with sulfides, whereas $\mathrm{Cu}$ is also a lithophile element. Thus, $\mathrm{Cu}$ tends to be a residue in the magma, whereas Pd is hosted in the sulfides when the magmas are Ssaturated. Consequently, the relationship between $\mathrm{Cu}$ and $\mathrm{Pd}$

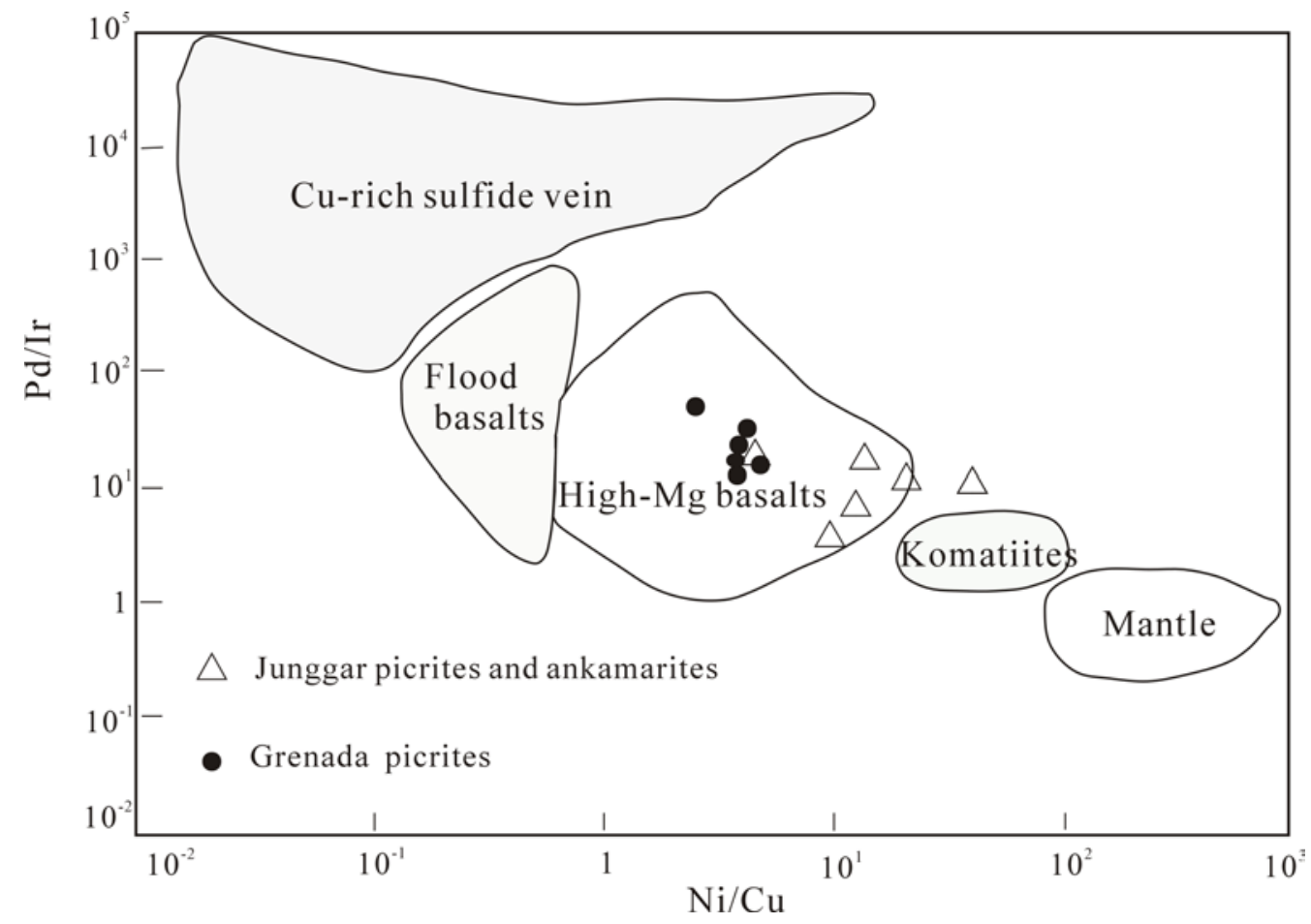

Fig. (6). Pd/Ir versus Ni/Cu diagram (after [46]). Grenada picrites are shown for comparison. 
has been utilized by some researchers to assess the extent of sulphur saturation in magmatic rocks [41, 51]. All samples plot in the field of S-undersaturated magmas, suggesting that the primary magmas in the Junggar arc were S-undersaturated.

\subsection{Constraints on the Geochemical PGE Behavour in Subduction System}

Until now, little was known about the behaviour of PGE during subduction, because only a few PGE data from arc volcanic rocks have been reported. Although PGE abundances of the Junggar picrites are slightly higher than the Grenada picrites in the Lesser Antilles, their primitive mantle normalized PGE patterns are quite similar (Fig. 4), suggesting that the PGE behaviour in both subduction zones was similar. The low overall PGE concentrations in the Junggar picritic lavas suggest that the PGEs are not highly mobile in slab-derived fluids. However, Ir contents of the Junggar picritic rocks are relatively lower, $<1 \mathrm{ppb}$, relative to Os and $\mathrm{Ru}$. This might imply that Ir is quite immobile, and not transported with slab-derived fluids. The same conclusion was reached by Borg et al. who studied the Cascade arc, U.S.A. [52]. As discussed above, the superchondritic Os/Ir ratios can be ascribed to the involvement of subducted plegic sediments in the mantle wedge.

Based on the PGE geochemistry of mantle peridotites in subduction zones, Rehkämper et al. concluded that the average $\mathrm{Pd} / \mathrm{Ir}$ ratio of the mantle peridotites in subduction zones is 1.28 [3]. The Junggar picritic rocks have much higher $\mathrm{Pd} / \mathrm{Ir}$ ratios, yielding an average ratio of 12 (Table 1), which is lower than those from the Grenada picrites in the Lesser Antilles (averaging 33.4). There are two possibilities for explaining the elevated $\mathrm{Pd} / \mathrm{Ir}$ ratios. One is related to low degrees of partial melting, because IPGEs such as Ir are thought to be hosted within silicate grains, whereas the PPGEs such as Pd are more likely to occur as sulfides, thus easily accessed during partial melting events [53]. Another possibility is metasomatism by fluids or melts derived from the subducted slab, because Pd and Ir have different transport abilities in the fluids [54]. McInnes et al. found that PGE enrichment in veined, arc mantle-harzburgites metasomatized by slab-derived, oxidizing, hydrous fluids from Lihir Island, Papua New Guinea is in the order $\mathrm{Pd}>\mathrm{Pt}>\mathrm{Re}>\mathrm{Os}$ [55]. In the Kamchatka arc, depleted, unmetasomatized harzburgites display relatively low $\mathrm{Pt}$ and $\mathrm{Pd}$ contents, and chondritic $\mathrm{Pd} / \mathrm{Ir}$ ratios, whereas metasomatized pyroxenite and wehrlite veins exhibit negative Ir anomalies on chondrite-normalized noble metal patterns [56]. These studies suggest that $\mathrm{Pd}$ and $\mathrm{Pt}$ may be more readily mobilized than the other PGE in the mantle wedge. Thus, partial melt derived metasomatized mantle should have elevated $\mathrm{Pd} / \mathrm{Ir}$ ratios. Based on the modeling by incompatible element ratios, Zhang et al. conclude that the primary magma for the Devonian arc volcanic rocks was generated by $15 \%$ melting of a mixed mantle peridotite in the garnet-spinel facies [38]. Consequently, we infer that high $\mathrm{Pd} / \mathrm{Ir}$ ratios cannot be attributed to low degrees of melting of mantle, but may be caused by metasomatism of fluids or melts derived from subducted slabs because they have much higher $\mathrm{Pd} / \mathrm{Ir}$ ratios [57]. This view is in accord with our previous conclusion from the trace element geochemistry of picrites [38].

\section{CONCLUSIONS}

1. The picrites and ankaramites of the middle Devonian Beitashan Formation in the Junggar terrane originated from the incompatible elements-depleted asthenospheric mantle containing subducted plegic sediments.

2. The picrites and ankaramites of the Beitashan Fm. were not the counterpart of the primary magmas, but derived from high-Mg basalts with excess olivine and clinopyroxene accumulation respectively, and the primary magma is S-undersaturated.

3. The PPGE may have slightly enhanced transport efficiency in slab-derived fluids compared to IPGE. The primitive mantle normalized PGE patterns of the picrites and ankaramites in the Junggar terrane are similar to those of arc picrites, suggesting that melts generated in a subduction regime may have common characteristics.

\section{ACKNOWLEDGEMENTS}

This material is based upon work supported by NSFC grant (40772045, 40572047), Program for New Century Excellent Talents in University (NCET-04-0728), and the 111 Project (B07011). We are grateful to Dr. A.D. Du for assistance with the PGE determination. Four anonymous reviewers are thanked very much for their time and constructive suggestions.

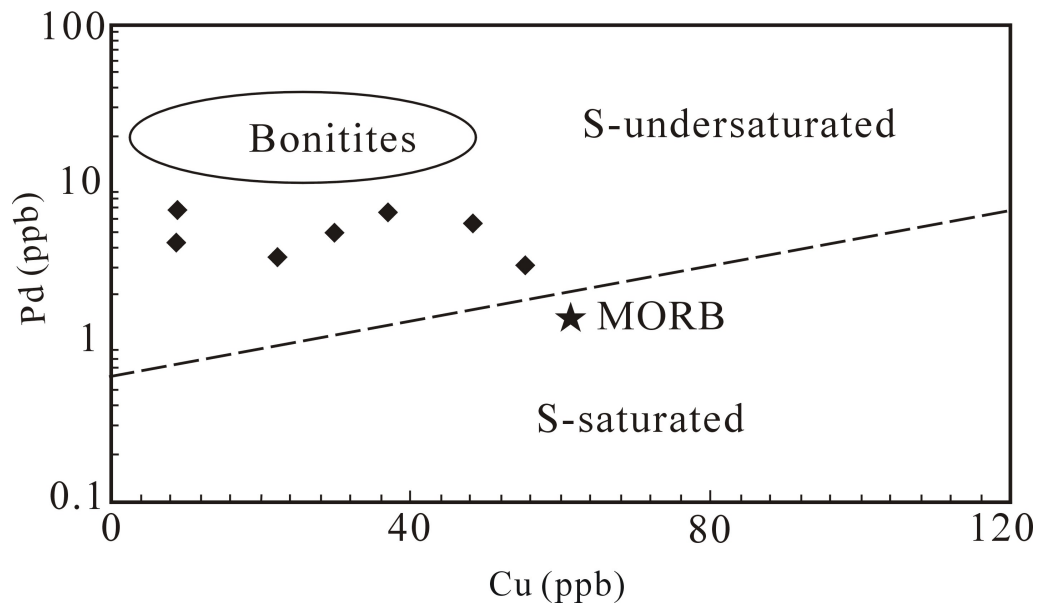

Fig. (7). $\mathrm{Pd}$ vs $\mathrm{Cu}$ as a potential measure of $\mathrm{S}$ saturation (after [51]). 


\section{REFERENCES}

[1] Brandon, A.D.; Walker, R.J.; Morgan, J.W.; Norman, M.D.; Pichard, H.M. Coupled ${ }^{186} \mathrm{Os}$ and ${ }^{187} \mathrm{Os}$ evidence for core-mantle interaction. Science, 1998, 280, 1570-1573.

[2] Puchtel, I.S.; Humayun, M. Platinum group elements in Kostomuksha komatiites and basalts: Implications for oceanic crust recycling and core-mantle interaction. Geochim. et Cosmochim. Acta, 2000, 64, 4227-4242.

[3] Rehkämper, M.; Halliday, A.N.; Barfod, D.; Fitton, J.G. Platinumgroup element abundance patterns in different mantle environments. Science, 1997, 278, 1595-1598.

[4] Rehkämper, M.; Halliday, A.N.; Alt, J.; Fitton, J.G.; Zipfel, J.; Takazawa, E. Non-chondritic platinum-group element ratios in oceanic mantle lithosphere: petrogenetic signature of melt percolation? Earth Planet. Sci. Lett., 1999, 172, 65-81.

[5] Rehkämper, M.; Halliday, A.N.; Fitton, J.G.; Lee, D.C.; Wieneke, M.; Arndt, N.T. Ir, Ru, Pt, and Pd in basalts and komatiites: New constraints for the geochemical behavior of the platinum-group elements in the mantle, Geochim. et Cosmochim. Acta, 1999, 63, 3915-3934.

[6] Campbell, I.H.; Griffiths, R.W.; Hill, R.I. Melting in an Archaean mantle plume: heads it's basalts, tails it's komatiites. Nature, 1989, 339, 697-699.

[7] Storey, M.; Mahoney, J.J.; Kroenke, L.W.; Saunders, A.D. Are oceanic plateaus sites of komatiite formation? Geology, 1991, 19, 376-379.

[8] Herzberg, C. Generation of plume magmas through time: An experimental perspective. Chem. Geol., 1995, 126, 1-16.

[9] Le Bas, M.J. IUGS reclassification of the high-Mg and picritic volcanic rocks. J. Petrol., 2000, 41, 1467-1470.

[10] Larsen, L.M.; Pedersen, A.K.; Sundvoll, B.; Frei, R. Alkali picrites formed by melting of old metasomatised lithospheric mantle: Manîtdlat Member, Vaigat Formation, Palaeocene of West Greenland. J. Petrol., 2003, 44, 3-38.

[11] Perfit, M.R.; Fornari, D.J.; Ridley, W.I.; Kirk, P.D.; Casey, J.; Kastens, K.A.; Reynolds, J.R.; Edwards, M.; Desonie, D.; Shuster, R.; Paradis, S. Recent volcanism in the western Siqueiros Transform Fault: Picritic basalts and implications for MORB magma genesis. Earth Planet Sci. Lett., 1996, 141, 91-108.

[12] Nye, C.J.; Reid, M.R. Geochemistry of primary and least fractionated lavas from Okmok volcano, Central Aleutians: Implications for arc magmagenesis J. Geophys. Res., 1986, 91, 10271-10287.

[13] Woodland, S.J.; Pearson, D.G.; Thirwall, M.F. A Platinum Group Element and Re-Os Isotope Investigation of Siderophile Element Recycling in Subduction Zones: Comparison of Grenada, Lesser Antilles Arc, and the Izu-Bonin Arc. J. Petrol., 2002, 43, 171-198.

[14] Kamenetsky, V.S.; Sobolev, A.V.; Joron, J.L.; Semet, M.P. Petrology and geochemistry of cretaceous ultramafic volcanics from Eastern Kamchatka. J. Petrol., 1995, 36, 637-662.

[15] Yamamoto, M. Picritic primary magma and its source mantle for Oshima-Ōshima and back-arc side volcanoes, Northeast Japan Arc. Contrib. Mineral. Petrol., 1988, 99, 352-359.

[16] Eggins, S.M. Differentiation and evolution of arc picrites, Ambae (Aoba), Vanuatu. Contrib. Mineral Petrol, 1993, 114, 79-100.

[17] Cox, K.G.; Bell, J.D. A crystal fractionation model for the basaltic rocks of the New Georgia Group, British Solomon Islands. Contrib. Mineral. Petrol., 1972, 37, 1-13.

[18] Peate, D.A.; Pearce, J.A.; Hawkesworth, C.J.; Colly, H.; Edwards, C.M.; Hirose, K. Geochemical variations in Vanuatu Arc lavas: the role of subducted material and a variable mantle wedge composition. J. Petrol., 1997, 38, 1331-1358.

[19] Sengör, A.M.C.; Natal' in B.A.; Burtman, V.S. Evolution of the Altaid tectonic collage and Palaeozoic crustal growth in Eurasia. Nature, 1993, 364, 299-307.

[20] Zhang, Z.C.; Zhou, G.; Yan, S.H.; Chen, B.L.; He, Y.K.; Chai, F.M.; He, L.X. Geology and Geochemistry of the Late Palaeozoic Volcanic Rocks of the South Margin of the Altai Mountains and Implications for Tectonic Evolution. Acta Geol. Sin., 2007, 81, 344-358 (in Chinese with English abstract).

[21] Coleman, R.G. Continental growth of northwest China. Tectonics, 1989, $8,621-35$.

[22] Feng, Y.; Coleman, R.G.; Tilton, G.; Xiao, X. Tectonic evolution of the West Junggar region, Xinjiang, China. Tectonics, 1989, 8, 729-752.

[23] Jian, P.; Liu, D.Y.; Zhang, Q.; Zhang, F.Q.; Shi, Y.R.; Shi, G.H.; Zhang, L.Q.; Tao, H. SHRIMP dating of ophiolite and leucocratic rocks within ophiolite. Earth Science Frontiers, 2003, 10, 439-455 (in Chinese with English abstract).

[24] Tang, H.F.; Su, Y.P.; Liu, C.Q.; Hou, G.S.; Wang, Y.B. Zircon U$\mathrm{Pb}$ age of the Plagiogranite in Kalamali belt, Northern Xinjiang and its tectonic implications. Geotectonica et Metallogenia, 2007, 31 . 110-117 (in Chinese with English abstract).

[25] Han, B.F.; Wang, S.G.; Jahn, B.M.; Hong, D.W.; Kagami, H.; Sun, Y.L. Depleted-mantle magma source for the Ulungur River A-type granites from northern Xinjiang, China: Geochemistry and Nd-Sr isotopic evidence, and implication for Phanerozoic crustal growth. Chem. Geol., 1997, 138, 135-59.

[26] Zhang, Z.C.; Yan, S.H.; Chen, B.L.; Zhou, G.; He, Y.K.; Chai, F.M. He, L.X.; Wan, Y.S. SHRIMP zircon U-Pb dating for subduction-related granitic rocks in the northern part of east Junggar, Xinjiang. Chinese Sci. Bull., 2006, 51, 952-962.

[27] Jackson, S.E.; Fryer, B.J.; Gosse, W.D.; Healey, C.H.; Longerich, P.; Strong, D.F. Determination of the precious metals in the geological materials by inductively coupled plasma-mass spectrometery (ICP-MS) with nickel-sulfide fire-assay collection and tellurium coprecipitation. Chem. Geol., 1990, 83, 119-132.

[28] Ravizza, G.; Pyle, D. PGE and Os isotopic analyses of single sample aliquots with NiS fire assay preconcentration. Chem. Geol. 1997, 141, 251-268.

[29] Du, A.D. Preparation and certification of Re-Os dating Reference Materials: molybdenites HLP and JDC. Geostand. Geoanal. Res. 2004, 28, 41-52.

[30] Norrish, K.; Chappel, B.W. Physical Methods in Determinative Mineralogy, $2^{\text {nd }}$ ed. New York, Academic Press, 1997, 201-272.

[31] Dulski, P. Interferences of oxide, hydroxide and chloride analyses species in the determination of rare earth elements in geological samples by inductively coupled plama-mass spectrometry. Fresenius's J. Anal. Chem., 1994, 350, 194-203.

[32] Righter, K.; Hauri, E.H. Compatibility of rheniumin garnet during mantle melting and magma genesis. Science, 1998, 280, 17371741

[33] Burton, K.W.; Gannoun, A.; Birck, J.L.; Allègre, C.J.; Schiano, P.; Clocchiatti, R.; Alard, O. The compatibility of rhenium and osmium in natural olivine and their behaviour during mantle melting and basalt genesis. Earth Planet. Sci. Lett., 2002, 198, 63-76.

[34] Bennett, V.C.; Norman, M.D.; Garcia, M.O. Rhenium and platinum group element abundances correlated with mantle source components in Hawaiian picrites: sulphides in the plume. Earth Planet. Sci. Lett., 2000, 183, 513-26.

[35] Beswick, A.E. In: Arndt, N.T.; Nisbet, E.G. Eds. Komatiities George Allen and Unwin, London, 1982, pp. 283-308.

[36] Barnes, S.-J.; Naldrett, A.J.; Gorton, M.P. The origin of the fractionation of platinum-group elements in terrestrial magmas. Chem Geol., 1985, 53, 303-23.

[37] Crocket, J.H. PGE in fresh basalt, hydrothermal alteration products, and volcanic incrustations of Kilauea volcano, Hawaii. Geochim. Cosmochim. Acta., 2000, 64, 1791-807.

[38] Zhang, Z.C.; Mao, J.W.; Cai, J.H.; Zhou, G.; Yan, S.H.; Kusky, T.M. Geochemistry of picrites and associated lavas of a Devonian island arc in the Northern Junggar terrane, Xinjiang (NW China): implications for petrogenesis, arc mantle sources and tectonic setting. Lithos, 2008, 105, 379-395.

[39] Garuti, G.; Fershtater, G.; Bea, F.; Montero, P.; Pushkarev, E.V.; Zaccarini, F. Platinum-hroup elements as petrological indicators in mafic-ultramafic complexes of the central and southern Urals: preliminary results. Tectonophys., 1997, 276, 181-194.

[40] Thirlwall, M.F.; Graham, A.M.; Arculus, R.J.; Harmon, R.S.; MacPherson, C.G. Resolution of the effects of crustal assimilation, sediment subduction, and fluid transport in island arc magmas: $\mathrm{Pb}$ Sr-Nd-O isotope geochemistry of Grenada, Lesser Antilles. Geochim Cosmochim Acta, 1996, 60, 4785-4810.

[41] Brooks, C.K.; Keays, R.R.; Lambert, L.R.F.; Nielsen, T.F.D. Re-Os isotope geochemistry of Tertiary picritic and basaltic magmatism of East Greenland: constraints on plume-lithosphere interaction and the genesis of the Platinova Reef, Skaergaard Intrusion. Lithos, 1999, 47, 279-296.

[42] Ahmed, A.H.; Arai, S. Unexpectedly high-PGE chromitite from the deeper mantle section of the northern Oman ophiolite and its tectonic implications. Contrib. Mineral. Petrol., 2002, 143, 263-278.

[43] Lorand, J.P.; Schmidt, G.; Palme, H.; Kratz, K.L. Highly siderophile element geochemistry of the Earth's mantle: new data for the 
Lanzo (Italy) and Ronda (Spain) orogenic peridotite bodies. Lithos, 2000, 53, 149-164.

[44] Jaffe, L.A.; Peucker, E.B.; Petsch, S.T. Mobility of rhenium, platinum group elements and organic carbon during black shale weathering. Earth Planet. Sci. Lett., 2002, 198, 339-353.

[45] Zhang, Z.C.; Mahoney, J.J.; Mao, J.W.; Wang F.S. Geochemistry of picritic and associated basalt flows of the western Emeishan flood basalt province, China. J. Petrol., 2006, 47, 1997-2019.

[46] Chai, G.; Naldrett, A.J. Characteristics of Ni-Cu-PGE mineralization and genesis of the Jinchuan deposit, Northwest China. Econ. Geol., 1992, 87, 1475-1495.

[47] Burton, K.W.; Schiano, P.; Birck, J.L.; Allegre, C.J. Osmium isotope disequilibrium between mantle minerals in a spinel-lherzolite. Earth Planet. Sci. Lett., 1999, 172, 311-322.

[48] Handler, M.R.; Bennett, V.C. Behaviour of platinum-group elements in the subcontinental mantle of eastern Australia during variable metasomatism and melt depletion. Geochim. Cosmochim. Acta, 1999, 63, 3597-3618.

[49] Peach, C.L.; Mathez, E.A.; Keays, R.R. Sulfide melt-silicate melt distribution coefficients for noble metals and other chalcophile elements as deduced from MORB ; implications for partial melting. Geochim. Cosmochim. Acta, 1990, 54, 3379-3389.

[50] Fleet, M.E.; Crocket, J.H.; Stone, W.E. Partition of platinum-group elements (Os, Ir, Ru, Pt, Pd) and gold between sulfide liquid and basalt melt. Geochim. Cosmochim. Acta, 1996, 60, 2397-2412.

[51] Vogel, D.C.; Keays, R.R. The application of platinum group geochemistry in constraining the source of basalt magmas: results from Newer Volcanic Province, Victoria. Australia. Chem. Geol., 1997, 136, 181-204.

[52] Borg, L.E.; Brandon, A.D.; Cynne, M.A.; Walker, R.J. Re-Os isotopic systematics of primitive lavas from the Lassen region of the Cascade Arc. California. Earth Planet. Sci. Lett., 2000, 177, 301-317.

[53] Alard, O.; Griffin, W.L.; Lorand, J.P.; Jackson, S.E.; O’ Reilly, S.Y. Non-chondritic distribution of the highly siderophile elements in mantle sulphides. Nature, 2000, 407, 891-894.

[54] Lorand, J.P.; Keays, R.R.; Bodinier, J.I. Base- and noble-metal enrichment across the lithospheric-asthenospheric boundary of mantle diapiars: Evidence from the Lanze lherzolite massif. J. Petrol., 1993, 34, 1111-1140.

[55] McInnes, B.I.A.; McBride, J.S.; Evans, N.J.; Lambert, D.D.; Andrew, A.A. Osmium Isotope Contstraints on Ore Metal Recycling in Subduction Zones. Science, 1999, 286, 512-516.

[56] Kepezhinskas, P.; Defant, M.J.; Widom, E. Abundance and distribution of PGE and $\mathrm{Au}$ in the island-arc mantle: implications for sub-arc metasomatism. Lithos, 2002, 60, 113-128.

[57] Edwards, S.J. Harzburgites and refractory melts in the Lewis Hills massif, Bay of Islands ophiolite complex: The base-metals and precious-metals stiry. Can. Mineral., 1990, 28, 537-552.

[58] Jahn, B.M.; Wu, F.; Chen, B. Granitoids of the Central Asian Orogenic Belt and continental growth in the Phanerozoic. Trans. $R$ Soc. Edinburgh Earth Sci., 2000, 91, 181-193.

[59] Chen, B.; Jahn, B.M. Genesis of post-collisional granitoids and basement nature of the Junggar Terrane, NW China: Nd-Sr isotope and trace element evidence. J. Asian Earth Sci., 2004, 23, 691-703.

[60] Schaefer, B.F.; Parkinson, I.J.; Hawkesworth, C.J.; Czamanske, G.K. Deep mantle plume osmium signature from the West Greenland Tertiary picrites. Earth Planet Sci. Lett., 2000, 175, 105-118.

[61] Zhang, Z.C.; Mao, J.W.; Mahoney, J.J.; Wang, F.S.; Qu, W.J. Platinum Group Elements of the Emeishan Large Igneous Province: Implications for mantle sources. Geochem. J. 2005, 39, 371382 .

This is an open access article licensed under the terms of the Creative Commons Attribution Non-Commercial License (http://creativecommons.org/licenses/ by-nc/3.0/) which permits unrestricted, non-commercial use, distribution and reproduction in any medium, provided the work is properly cited. 